\title{
Characterization of Staphylococcus intermedius Group Isolates Associated with Animals from Antarctica and Emended Description of Staphylococcus delphini
}

\author{
Veronika Vrbovská $^{1}{ }^{\oplus}$, Ivo Sedláček ${ }^{2}$, Michal Zeman ${ }^{1,2} \oplus$, Pavel Švec ${ }^{2} \oplus$, Vojtěch Kovařovic ${ }^{1}$, \\ Ondrej Šedo ${ }^{3}$, Monika Laichmanová ${ }^{2}$, Jiří Doškař ${ }^{1}$ and Roman Pantůček ${ }^{1, * \mathbb{C}}$ \\ 1 Division of Genetics and Molecular Biology, Department of Experimental Biology, Faculty of Science, \\ Masaryk University, Kotlářská 2, 61137 Brno, Czech Republic; veronika.vrbovska@gmail.com (V.V.); \\ michal.zeman91@gmail.com (M.Z.); 408266@mail.muni.cz (V.K.); doskar@sci.muni.cz (J.D.) \\ 2 Czech Collection of Microorganisms, Department of Experimental Biology, Faculty of Science, \\ Masaryk University, Kamenice 5, 62500 Brno, Czech Republic; ivo@sci.muni.cz (I.S.); \\ mpavel@sci.muni.cz (P.Š.); monikadr@sci.muni.cz (M.L.) \\ 3 Central European Institute of Technology, Masaryk University, Kamenice 5, 62500 Brno, Czech Republic; \\ sedo@sci.muni.cz \\ * Correspondence: pantucek@sci.muni.cz; Tel.: +420-549-49-6379
}

Received: 29 November 2019; Accepted: 30 January 2020; Published: 1 February 2020

\begin{abstract}
Members of the genus Staphylococcus are widespread in nature and occupy a variety of niches, however, staphylococcal colonization of animals in the Antarctic environment has not been adequately studied. Here, we describe the first isolation and characterization of two Staphylococcus intermedius group (SIG) members, Staphylococcus delphini and Staphylococcus pseudintermedius, in Antarctic wildlife. Staphylococcus delphini were found exclusively in Adélie penguins. The report of S. pseudintermedius from Weddell seals confirmed its occurrence in all families of the suborder Caniformia. Partial RNA polymerase beta-subunit $(r p o B)$ gene sequencing, repetitive PCR fingerprinting with the $(\mathrm{GTG})_{5}$ primer, and matrix-assisted laser-desorption/ionization time-of-flight mass spectrometry gave consistent identification results and proved to be suitable for identifying SIG members. Comparative genomics of $S$. delphini isolates revealed variable genomic elements, including new prophages, a novel phage-inducible chromosomal island, and numerous putative virulence factors. Surface and extracellular protein distribution were compared between genomes and showed strain-specific profiles. The pathogenic potential of S. delphini was enhanced by a novel type of exfoliative toxin, trypsin-like serine protease cluster, and enterotoxin C. Detailed analysis of phenotypic characteristics performed on six Antarctic isolates of S. delphini and eight reference strains from different animal sources enabled us to emend the species description of S. delphini.
\end{abstract}

Keywords: Staphylococcus delphini; Staphylococcus pseudintermedius; Antarctica; mobile genetic elements; surface proteins; exfoliative toxin; Adélie penguin; Weddell seal

\section{Introduction}

Staphylococci are a major group of bacteria inhabiting the skin, skin glands, and mucous membranes of humans, other mammals, and birds, as well as the environment due to their ubiquity and adaptability [1]. However, there is very limited information available on staphylococcal isolates from Antarctica. Researchers have occasionally isolated staphylococcal strains from Antarctic environmental samples [2-6] and also from several animals obtained during their health evaluation, but they were mostly only classified to the genus level, such as isolates from whale wound lesions [7], a fish stomach [8], lesions on two dead Adélie penguins [9], or skin swabs of Weddell seals [10]. 
To the best of our knowledge, no member of the Staphylococcus intermedius group (SIG), which includes important veterinary pathogens, has been reported so far from animals in Antarctica. Originally, most isolates of SIG were classified as S. intermedius, before their subdivision into SIG members [11,12] comprised of the following four closely related but distinct coagulase-positive species: S. intermedius [13], S. pseudintermedius [14], S. delphini [15], and a human-originated S. cornubiensis [16]. The phenotypic and biochemical differentiation between the members of this group is complex and difficult and can result in unreliable species identification [17]. These species can be interchangeably misidentified as each other. Since SIG species are very similar to Staphylococcus aureus based on their clinical manifestations and biochemical characteristics such as coagulase positivity, SIG human clinical isolates have probably been misidentified as S. aureus in the past [18]. Protein profiling through matrix-assisted laser-desorption/ionization time-of-flight mass spectrometry (MALDI-TOF MS) seems to be the most reliable method to differentiate between SIG species $[19,20]$. Other effective methods for SIG diagnostics are sequencing of the housekeeping genes nuc [21], $\operatorname{sodA}$, and hsp60 [22], and for the discrimination of $S$. pseudintermedius by means of the pta housekeeping gene [23] or multilocus sequence typing (MLST) [24], as well as whole-genome sequencing [25,26].

SIG members are common colonizers of animal mucosal surfaces and are considered to be opportunistic pathogens in many infections of different animal hosts. Staphylococcal isolates from dogs previously identified as S. intermedius belong almost exclusively to the species S. pseudintermedius, while true $S$. intermedius are found predominantly in pigeons [11,12]. S. pseudintermedius is recognized as an important causative agent of pyoderma, dermatitis, and otitis externa in dogs, cats, horses, and other animals [27]. However, its host range is not restricted only to non-human animals, but colonization and zoonotic infections of humans are increasingly recognized [28-34]. The taxonomic description of S. delphini, in 1988 [15], was based on two strains isolated from purulent skin lesions of two dolphins. Recently, developments in diagnostics have led to the detection of S. delphini in a broad range of animals [11,12,35] and one reported human case, probably of zoonotic origin [36]. According to the multilocus sequence analysis of the $\operatorname{sod} A, h s p 60$, and nuc genes, S. delphini is divided into two phylogenetically distinct clades; group A closely related to the S. delphini type strain, and group B related to the $S$. pseudintermedius type strain [12]. The large number of different host associations suggests that multiple ecovars can exist among $S$. delphini isolates.

The aim of this study was to describe the SIG isolates from mammals and birds on James Ross and Seymour Islands in Antarctica, with a focus on Staphylococcus delphini. The SIG strains were characterized in detail by phenotypic and genotypic techniques and based on the results an emended description of S. delphini was provided.

\section{Materials and Methods}

\subsection{Bacterial Strains and Their Biochemical Characterization}

Bacterial strains were collected over the years from 2013 to 2019 on James Ross Island and Seymour Island, Antarctica (Figure 1). The sampling was a part of the Cultivable Fecal Bacteria Communities study, which was part of the CzechPolar project. Sampling intensity varied considerably with geographic location and weather conditions. The key element in the distribution of sampling intensity was the ice-free coast of James Ross and Seymour Islands. There are no seal colonies occupying littoral zone of both islands and samples were taken from occasionally found seals sunning on the coast. Penguin rookeries are in Seymour Island but only the droppings were collected in this territory for protection of the birds. Additional samples from penguins were taken by random sampling when penguins occurred on the coast. All samples originated from live animals only and the sampling procedure was fast to prevent any stress to the animals. The samples from the beak and cloaca of Adélie penguins (Pygoscelis adeliae) (82 specimens), the fresh droppings of South polar skua (Stercorarius maccormicki) (14 specimens), and kelp gull (Larus dominicanus) (11 specimens), and the anus and mouth of Weddell seals (Leptonychotes weddellii) (244 specimens), and Southern elephant 
seals (Mirounga leonina) (12 individuals) were collected using the swab/transport tube system E-Swab (Dispolab, Brno, Czech Republic) and cultured on Mannitol Salt Agar (HiMedia Laboratories, Mumbai, India) at $35^{\circ} \mathrm{C}$ for several days in the laboratory at J.G. Mendel Base, James Ross Island. Colonies with suspected staphylococcal morphology were picked daily, kept at $4{ }^{\circ} \mathrm{C}$ and transferred to the $\mathrm{Czech}$ Republic for further analyses.

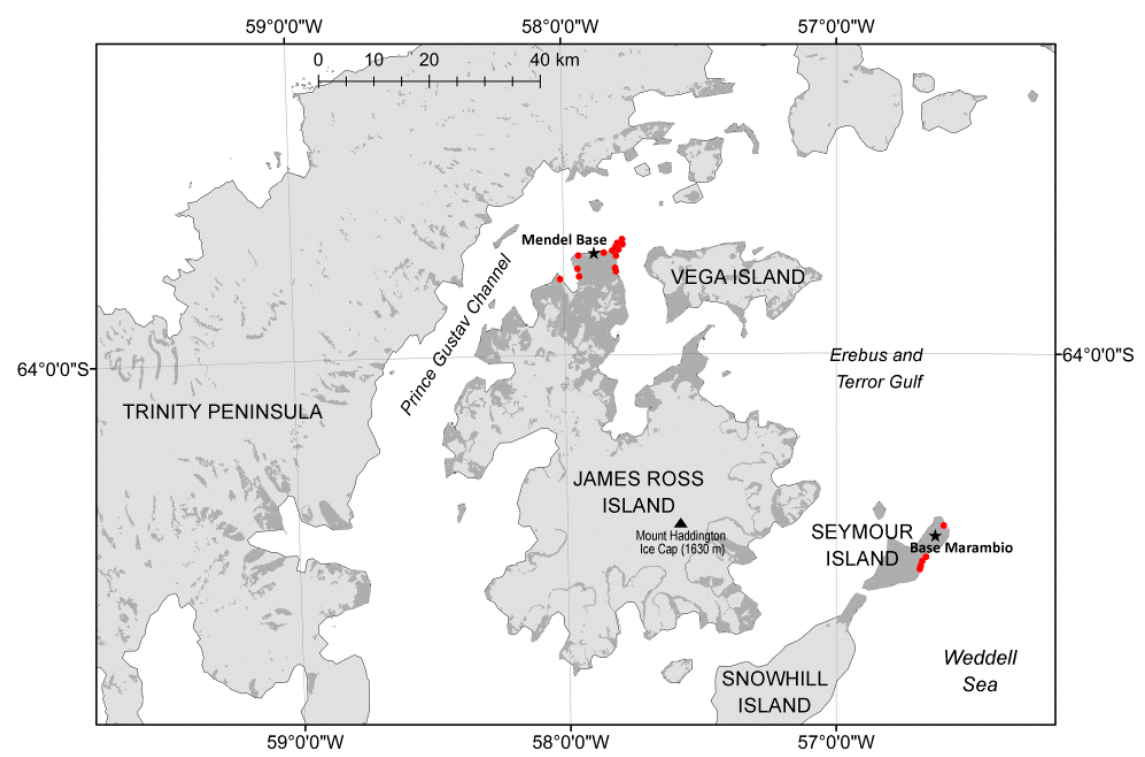

Figure 1. Sampling localities on James Ross Island and Seymour Island. Red mark, location of sampling site; asterisk, location of Antarctic base station; dark grey color, unglaciated area.

Type strains of S. delphini CCM $4115^{\mathrm{T}}$, S. intermedius CCM 5739 , S. pseudintermedius CCM $7315^{\mathrm{T}}$, and S. cornubiensis CCM $8997^{\mathrm{T}}$ were acquired from the Czech Collection of Microorganisms (Brno, Czech Republic). Reference strains of S. delphini: Nono (=CCM 4184)/dolphin/, CCM 2618 (=CCUG 51769)/mink/, P12548, P12549, and P12550 (=16-9169-2, 17-7762-1, and 18-3863-5, respectively) /all from minks/ [37], P12456 (=HT 2030677)/camel/, P12457 and P12458 (=8086 and 9106)/both from horses/ [11] and CCM 8998 (=MI 18-1587)/human/ [36] were described previously and kindly provided by the authors.

The phenotypic characterization of SIG strains was performed using the commercial kits API 50 $\mathrm{CH}$ and API ZYM (bioMérieux, Craponne, France) and by conventional physiological, biochemical, and growth tests discriminative for the genus Staphylococcus as described previously [2].

\subsection{Partial $16 S$ rRNA and RNA polymerase beta-subunit (rpoB) Gene Sequencing and Phylogenetic Analysis}

Partial 16S rRNA gene amplification was performed as described previously [38]. PCR amplicons were sequenced with primer 553L in Eurofins Genomics sequencing facility (Ebersberg, Germany). Sequences were identified using the EzTaxon database [39].

Partial RNA polymerase $\beta$-subunit $(r p o B)$ gene amplification was performed as described previously [40]. PCR amplicons obtained with the primers $1418 \mathrm{~F}$ and $3554 \mathrm{R}$ were sequenced with primers 1418F and 1876R in Eurofins Genomics. Phylogenetic relationships were computed with the software MEGA version 10 [41]. Partial rpoB gene sequences were deposited into the GenBank/ENA/DDBJ database under accession numbers MN729216-MN729246.

\section{3. $\operatorname{Rep}-P C R$}

Repetitive PCR fingerprinting with the (GTG) $)_{5}$ primer (rep-PCR) was performed as described previously [42]. Numerical analysis of the fingerprints and dendrogram construction was completed using the software BioNumerics version 7.6 (Applied Maths, Kortrijk, Belgium) and compared to 
the in-house Czech Collection of Microorganisms rep-PCR database of type and reference strains representing hitherto described Staphylococcus spp.

\subsection{MALDI-TOF MS}

Protein fingerprints by MALDI-TOF MS were acquired with an ultrafleXtreme instrument (Bruker Daltonics, Bremen, Germany) by following the ethanol/formic acid extraction protocol [43]. As many as nine independent mass spectra were acquired for each sample, and only signals present in the minimum of seven of these mass spectra were used for the identification and cluster analysis. The mass spectral data were compared with entries in the latest version of the Biotyper database (version 9.0.0.0, 8468 references) and their mutual similarity was expressed by $\log$ (scores), where scores greater than 2.000 correlate to species identification with high confidence, $\log$ (score) values between 1.700 and 1.999 correspond to species identification with low confidence, and $\log ($ score) values lower than 1.699 result in no identification. A MALDI-TOF MS-based dendrogram was constructed with the software Biotyper (version 3.1, Bruker Daltonics) using the Pearson's product moment similarity coefficient and the unweighted pair group method with arithmetic average (UPGMA) as a grouping method.

\subsection{Whole Genome Sequencing and Bioinformatic Analyses}

Genomic DNA was isolated using a High Pure PCR Template Preparation Kit (Roche Diagnostics, Mannheim, Germany) according to the manufacturer's instructions with the modification of adding $20 \mu \mathrm{L}$ of lysostaphin $\left(0.5 \mathrm{mg} \mathrm{mL}^{-1}\right)$ for cell lysis. An Illumina NextSeq sequencing platform was used for whole-genome shotgun sequencing of the strains P5747, P6456, and P8688. The purified genomic DNA was used for the preparation of a 500-bp sequencing library with a NEBNext@Ultra ${ }^{\mathrm{TM}}$ II DNA Library Prep Kit for Illumina (New England Biolabs, Ipswich, MA, USA). The samples were sequenced using a MID output cartridge in a 150-bp paired-end mode (Illumina, San Diego, CA, USA). The quality of sequencing reads was analyzed with FastQC version 0.11.8 [44]. Bases of lower quality and adapters were trimmed using the Spades version 3.13 implementation of BayesHammer. The de novo assembly of trimmed reads was performed with Spades version 3.13 [45], all k-mers 21 to 127 and follow-up mismatch correction. The package BBMap version 38.73 was used to analyze various statistics of genomes [46]. Contigs of described S. delphini genomes were reordered according to the reference genome of S. delphini strain NCTC $12225^{\mathrm{T}}$ (GenBank accession no. LR134263, NCTC 3000 Project) by Mauve Contig Mover as a part of Mauve version 2.4 [47]. The sequences of strains P5747, P6456, and P8688 were annotated by Prokka version 1.13.7 [48]. Subcellular localization of proteins of strains was predicted using PSORTb version 3.0 [49]. Proteins assigned to extracellular or cell wall categories were classified to gene ontology by cell2go [50]. Virulence factors were predicted using the VFanalyzer tool available at the Virulence Factors Database [51]. OrthoVenn2 [52] was used to cluster predicted proteins to orthologous groups. Web-based tools PHASTER [53], CRISPR-Cas++ [54], and GView [55] were employed to find mobile genetic elements and dissimilar regions between analyzed genomes. Sequences were manipulated and examined in the cross-platform software Ugene version 1.31.1 [56]. The multiple sequence alignment was visualised using EasyFig version 2.3 [57].

Whole genome-based phylogenetic analysis was also carried out in order to check the species status of SIG isolates. Average nucleotide identity values (ANI) were calculated with OrthoANIu version 1.2 [58] and digital DNA-DNA hybridization $(\mathrm{dDDH})$ values with the Genome-to-Genome Distance Calculator (GGDC) version 2.1 using the formula 2 recommended for draft genomes [57]. Up-to-date Bacterial Core Gene set (UBCG) software version 3.0 [59] was used to compare 92 core genes between $S$. delphini strains.

Assembly accession numbers of genomes retrieved from NCBI genome database are as follows: 8086 (GCF_000308115.1) [25], NCTC 12225 ${ }^{\mathrm{T}}$ (GCF_900636325.1), LMG 22219 ${ }^{\mathrm{T}}$ (GCF_001792775.2), NCTC 11048 ${ }^{\mathrm{T}}$ (GCF_900458545.1) [60], NW1 ${ }^{\mathrm{T}}$ (GCF_900183575.1) [16], 14S03309-1 (GCF_002374115.1), 14S03313-1 (GCF_002374125.1), 14S03318-1 (GCF_002369645.1), and 215100905101-2 (GCF_002369695.1) [26]. 
The Whole-Genome Shotgun projects of the S. delphini strains P5747 and P6456, and S. pseudintermedius P8688 have been deposited in DDBJ/ENA/GenBank under the accession numbers WNLD00000000, WNLE00000000, and JAACIP000000000, respectively.

\section{Results}

\subsection{Bacterial Strain Collection and Identification of Staphylococci}

During the austral summers from 2013 to 2019 on James Ross Island and Seymour Island, Antarctica, a total of 363 animal-related samples were collected in order to isolate staphylococcal species. The swabbed seals and penguins exhibited no disease symptoms at the time of sampling. Pure cultures of Gram-positive, catalase-positive cocci, able to grow in the presence of $12 \% \mathrm{NaCl}$, resistant to bacitracin and susceptible to furazolidone were chosen for partial 16S rRNA gene sequencing. In total, 150 Staphylococcus spp. strains were identified and most of them classified to the species level (Table S1). The most prevalent staphylococcal isolates were Staphylococcus haemolyticus ( $n=28$, predominantly in seals and droppings of skua), Staphylococcus epidermidis ( $n=22$, seals only), Staphylococcus intermedius group $(n=22$, seals and penguins), Staphylococcus sciuri ( $n=18$, predominantly in penguins and droppings of skua), Staphylococcus aureus/Staphylococcus argenteus/Staphylococcus schweitzeri complex ( $n=14$, in all sources), Staphylococcus capitis/Staphylococcus caprae complex ( $n=12$, seals only), Staphylococcus saprophyticus/Staphylococcus edaphicus complex $(n=9$, predominantly in seals), and Staphylococcus schleiferi subsp. coagulans ( $n=6$, in all sources).

Twenty-two of the 150 strains were originally identified as members of the Staphylococcus intermedius group based on partial 16S rRNA gene sequencing. The strains of SIG were further characterized in detail by genotypic and phenotypic methods and compared with the type strains S. delphini CCM $4115^{\mathrm{T}}$, S. intermedius CCM 5739 ${ }^{\mathrm{T}}$, S. pseudintermedius CCM 7315 $\mathrm{T}$, and S. cornubiensis CCM 8997 ${ }^{\mathrm{T}}$, as well as with $S$. delphini reference strains CCM 4184, CCM 2618, P12456, P12457, P12458, P12548, P12549, P12550, and CCM 8998 isolated previously from various sources.

\section{2. rpoB Gene Sequencing}

Since $16 \mathrm{~S}$ rRNA analysis has limited discriminatory power for identifying some staphylococcal species, the phylogenetic position of SIG strains assigned by the 16S rRNA gene sequencing was assessed using the sequence data of the partial rpoB gene that was previously shown to be effective for the species differentiation of staphylococci [40,61]. The computed neighbor-joining phylogenetic tree based on the partial rpoB gene sequence showed that SIG isolates clustered into two major groups corresponding to $S$. delphini and S. pseudintermedius (Figure 2). Strains recovered from Adélie penguins clustered together with the $S$. delphini type strain CCM $4115^{\mathrm{T}}$, whereas strains isolated from Weddell seals created a cluster with $S$. pseudintermedius type strain CCM $7315^{\mathrm{T}}$.

\subsection{Repetitive Sequence-Based PCR (Rep-PCR) Fingerprinting}

The repetitive sequence-based PCR (rep-PCR) fingerprinting technique using the $(\mathrm{GTG})_{5}$ primer placed the SIG isolates into two clusters corresponding to S. delphini and S. pseudintermedius at the similarity level of $54 \%$ and clearly separated them from S. intermedius and S. cornubiensis type strains (Figure 3). These results confirmed the rpoB-based identification of these strains. S. delphini strains exhibited more variable profiles (74\% to $100 \%$ similarity between strains) than $S$. pseudintermedius (80\% to 98\%). Five S. delphini strains P5747, P5749, P5833, P5835, and P6070 were closely related, while strain P6456 separated from them and clustered together with the S. delphini P12458 strain recovered from horse nasal swab. 


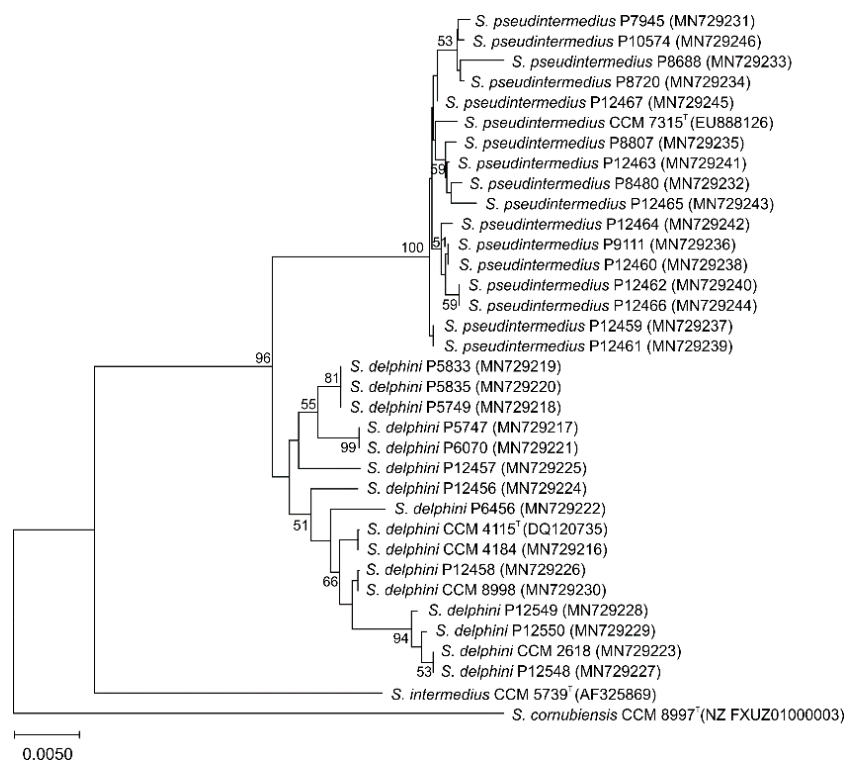

Figure 2. Unrooted neighbor-joining tree based on partial RNA polymerase beta-subunit (rpoB) gene sequence comparison, showing the clustering of Antarctic Staphylococcus intermedius group isolates and type and reference strains. The percentage of 500 tree replications above $50 \%$ in which the associated strains clustered together is shown next to the branches. The tree is drawn to scale, with branch lengths in the same units as those of the evolutionary distances used to infer the phylogenetic tree. The evolutionary distances were computed using the Tajima-Nei method and are in the units of the number of base substitutions per site. All ambiguous positions were removed for each sequence pair (pairwise deletion option). There was a total of 845 positions in the final dataset.

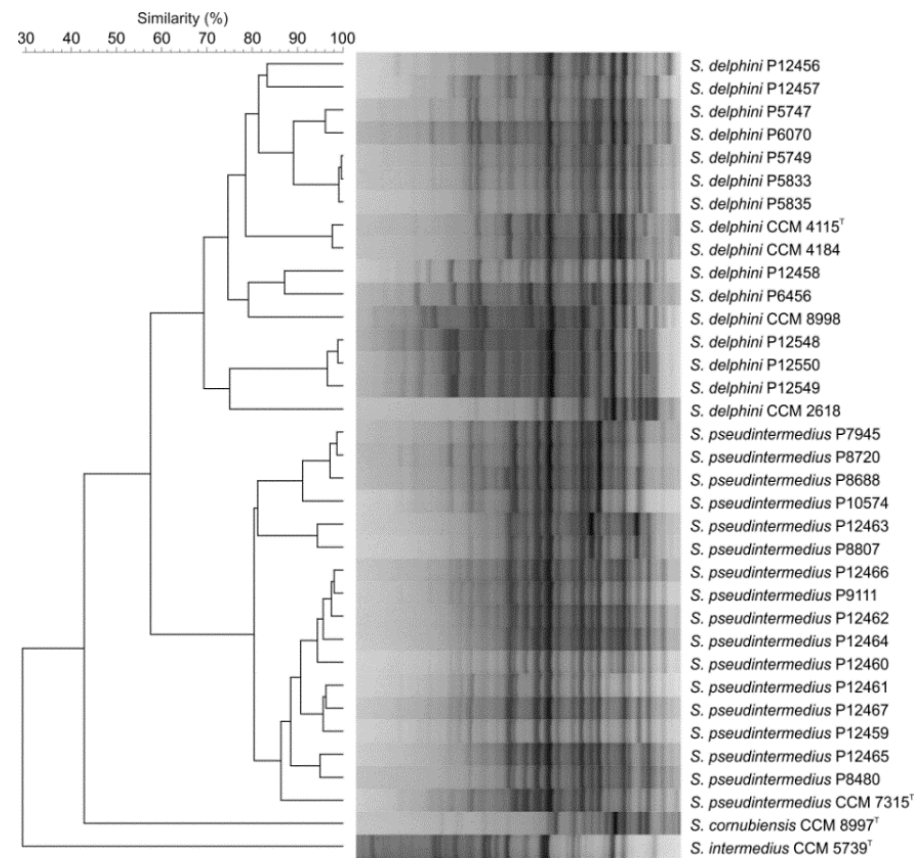

Figure 3. Dendrogram based on cluster analysis of repetitive sequence-based PCR (rep-PCR) fingerprints obtained with (GTG) 5 primer from analyzed isolates and type and reference strains of Staphylococcus intermedius group. The dendrogram was calculated with Pearson's correlation coefficients with unweighted pair group method with arithmetic average (UPGMA) clustering method ( $r$, expressed as percentage similarity values). 


\subsection{MALDI-TOF MS}

All SIG isolates and reference strains were analyzed by MALDI-TOF MS fingerprinting. Out of the S. delphini strains involved in the study, 14 were assigned to $S$. delphini entries of the Biotyper database (six with high confidence and eight with low confidence), while two strains, P5747 and P6070, did not exhibit significant similarity to any of the database entries. All sixteen S. delphini strains shared several signals (3787, 4111, 4278, 5302, 6241, 6341, 7438, 8032, 8147, 9028, 9649, and 10506 Da; detected doubly protonated forms of these proteins are not listed), while no peaks characteristic of the strain origin (isolation source/region) were found.

As for S. pseudintermedius strains, 13 strains were identified accordingly by using the Biotyper Database (two with high confidence and 11 with low confidence), while the four remaining strains (P7945, P8807, P9111, and P12464) did not exhibit significant similarity to any of the database entries. All 17 S. pseudintermedius strains shared several peaks $(4278,5303,5843,6241,6875,7438,8032,8147$, $8622,8649,9028,10081$, and $10506 \mathrm{Da}$; detected doubly protonated forms of these proteins are not listed). Seven signals shared by all strains of S. delphini and S. pseudintermedius $(4278,6241,7438,8032$, 8147,9028 , and $10506 \mathrm{Da}$ ) indicate the close relatedness of these two species. MALDI-TOF MS-based identification outputs correlated with the dendrogram derived from the protein signals (Figure 4). In addition, two S. delphini strains, P5747 and P6070, and four S. pseudintermedius strains, P7945, P8807, P9111, and P12464 unassigned to S. delphini or S. pseudintermedius by the MALDI MS-based scoring identification workflow and grouped using cluster analysis (Figure 4) in agreement with the rpoB-based and rep-PCR identification (Figure 3).

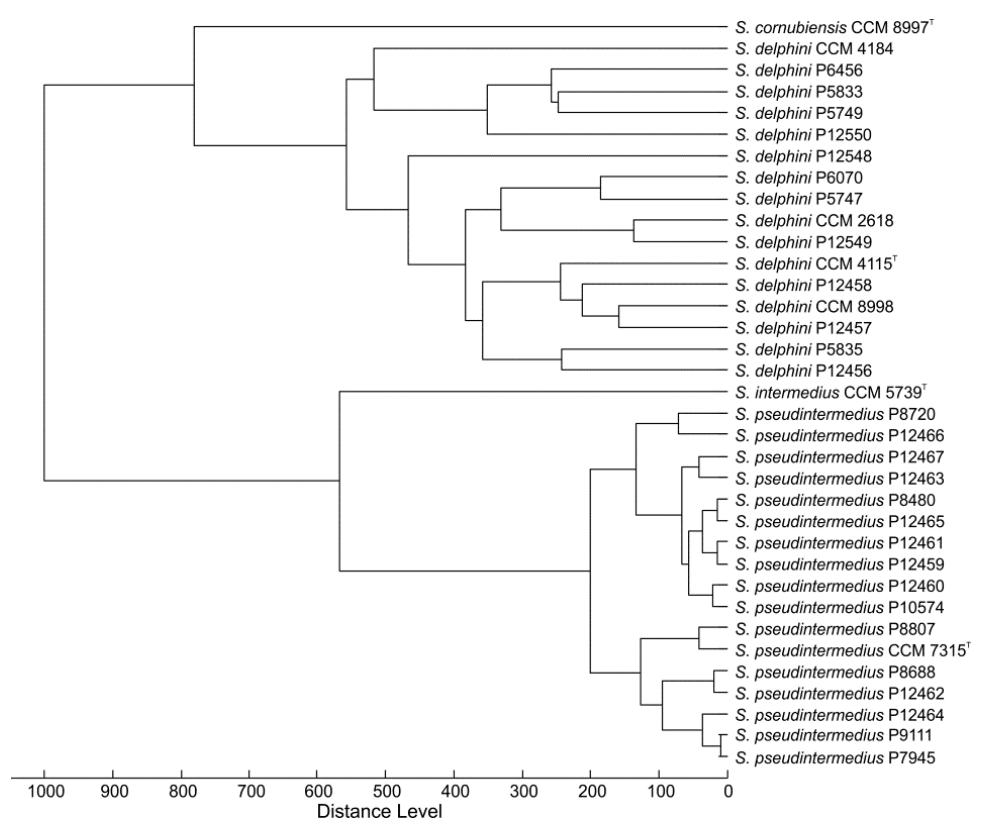

Figure 4. Matrix-assisted laser-desorption/ionization time-of-flight (MALDI-TOF) mass spectra-based dendrogram of analyzed isolates and type and reference strains of Staphylococcus intermedius group. The dendrogram was constructed using Pearson's product moment coefficient as a measure of similarity and the unweighted pair group average linked method (UPGMA) as a grouping method.

\subsection{Biochemical Identification}

The physiological and biochemical properties of SIG Antarctic isolates and 13 strains isolated from other sources were examined (Table 1). Antarctic isolates of both S. delphini and S. pseudintermedius phenotypically do not correspond to previously described profiles of the species and did not allow their correct classification. Contrary to the original description, all the studied S. delphini strains were gelatinase positive, but lecithinase negative and produced acid from trehalose. Coagulase, arginine 
dihydrolase, urease, hydrolysis of Tween 80 , acid production from glycerol, mannitol, $\beta$-gentiobiose, or turanose were strain-dependent for S. delphini (Table 1). Similarly, S. pseudintermedius from seals differs from the valid description by negative acetoin production and gave variable results for coagulase, arginine dihydrolase, and growth at $45^{\circ} \mathrm{C}$ and acid production from mannitol, $\alpha$-methyl-D-glucoside, and turanose (Table 1). Species from SIG are closely related and phenotypic classification to the species level remains insufficient due to the already reported lack of distinguishable biochemical tests for correct and reliable identification [11,12]. Phenotypic tests applicable for the presumptive species identification of SIG members based on our study, especially for S. delphini and S. pseudintermedius, are summarized in Table 2.

All strains were positive for the following conventional tests: production of catalase, growth in $12 \% \mathrm{NaCl}$, bacitracin resistance, furazolidone and novobiocin susceptibility, production of DNase, pyrrolidonyl arylamidase, nitrate reduction, and growth at $37{ }^{\circ} \mathrm{C}$. Negative for production of oxidase, starch hydrolysis, and growth at $20^{\circ} \mathrm{C}$ and $48{ }^{\circ} \mathrm{C}$, production of ornithine decarboxylases, and Voges-Proskauer (acetoin). With the API ZYM kit, positive reactions were obtained for the enzymatic activity of alkaline phosphatase, acid phosphatase, esterase (C4), esterase-lipase (C8), leucine arylamidase and $\beta$-galactosidase; and negative reactions for the enzymes lipase (C14), valine arylamidase, cystine arylamidase, trypsin, $\alpha$-chymotrypsin, naphthol-AS-BI-phosphohydrolase, $\alpha$-galactosidase, $\beta$-glucuronidase, $\alpha$-glucosidase, $\beta$-glucosidase, $\mathrm{N}$-acetyl- $\beta$-glucosaminidase, $\alpha$-mannosidase, and $\alpha$-fucosidase. In the API $50 \mathrm{CH}$ tests, all strains gave positive reactions for acid production from glycerol, ribose, galactose, glucose, fructose, mannose, N-acetyl-glucosamine, maltose, lactose, and sucrose. Negative acid production from erythritol, D-arabinose, L-arabinose, D-xylose, L-xylose adonitol, $\beta$-methyl-D-xyloside, sorbose, rhamnose, dulcitol, inositol, sorbitol, $\alpha$-methyl-D-mannoside, amygdalin, arbutin, salicin, celobiose, melibiose, inulin, melezitose, raffinose, starch, glycogen, xylitol, D-lyxose, D-tagatose, D-fucose, L-fucose, D-arabitol, L-arabitol, D-gluconate, 2-keto-gluconate, and 5-keto-gluconate; and negative esculin hydrolysis.

\subsection{Comparative Genomic Analysis of Staphylococcus delphini Isolates}

Two genomes of S. delphini Antarctic strains that differed from each other in several characteristics were shotgun sequenced and annotated. Strain P5747 was not successfully identified by the MALDI-TOF MS scoring algorithm, was urease negative, and did not produce acid from lactose; strain P6456 formed a distant cluster in the rep-PCR based dendrogram and $r p o B$ gene phylogenetic tree and did not produce acid from mannitol. The size of the draft genomes of strains P5747 and P6456 was 2.54 and $2.65 \mathrm{Mb}$, comprised of 47 and 104 contigs, with an average G+C content of 38.2 and $38.1 \mathrm{~mol} \%$, respectively (Table S2). The genome assemblies were compared to whole-genome sequences of $S$. delphini type strain NCTC $12225^{\mathrm{T}}$ and horse isolates S. delphini 8086 [25] and S. delphini 215100905101-2 [26] (Figure 5). Comparative genomic analysis of predicted genes in the above five genomes identified 2460 gene clusters and 596 singletons. The majority of the orthologous clusters (up to 1899) were shared by all the analyzed strains. Fifty-six clusters were unique for Antarctic strains and responsible for plasmid maintenance, phage DNA replication, and a response to phosphate starvation. All non-Antarctic S. delphini strains have additional genes for biofilm formation, the regulation of L-carnitine utilization, and a phosphoenolpyruvate-dependent sugar phosphotransferase system. Antarctic S. delphini lack the presence of the genes that confer resistance to fosfomycin as compared with the strains of equine origin. 
Table 1. Variable phenotypic reactions of Staphylococcus intermedius group strains under study.

\begin{tabular}{|c|c|c|c|c|c|c|c|c|c|c|c|c|c|c|c|c|c|c|c|c|c|c|}
\hline \multirow{2}{*}{ Species } & \multirow{2}{*}{ Strain } & \multirow{2}{*}{ Source } & \multirow{2}{*}{ Locality } & \multicolumn{8}{|c|}{ Conventional Test Results } & \multicolumn{9}{|c|}{ API $50 \mathrm{CH}$} & \multicolumn{2}{|c|}{ API ZYM } \\
\hline & & & & $\mathrm{COA}$ & ARG & URE & TWE & GEL & Cas & E-Y & C45 & GLY & MAN & SOR & ARB & MDG & LAC & TRE & GEN & TUR & N-PH & $\alpha-\mathrm{FU}$ \\
\hline S. delphini & $\mathrm{CCM} 4115^{\mathrm{T}}$ & dolphin & Italy & + & + & + & - & - & - & + & + & $\mathrm{w}$ & + & - & - & - & + & - & - & $\mathrm{w}$ & - & - \\
\hline S. delphini & CCM 4184 & dolphin & Italy & + & $\mathrm{w}$ & + & - & - & - & + & + & $\mathrm{w}$ & + & - & - & - & + & - & - & $\mathrm{w}$ & - & - \\
\hline S. delphini & P5747 & penguin & Antarctica & $\mathrm{w}$ & - & - & $\mathrm{w}$ & + & + & - & + & - & $\mathrm{w}$ & - & - & - & - & + & - & $\mathrm{w}$ & - & - \\
\hline S. delphini & P5749 & penguin & Antarctica & $\mathrm{w}$ & $\mathrm{w}$ & + & + & + & + & - & + & $\mathrm{w}$ & $\mathrm{w}$ & - & - & - & + & + & - & $\mathrm{w}$ & - & - \\
\hline S. delphini & P5833 & penguin & Antarctica & $\mathrm{w}$ & - & + & + & + & + & - & + & $\mathrm{w}$ & + & - & - & - & + & + & - & $\mathrm{w}$ & - & - \\
\hline S. delphini & P5835 & penguin & Antarctica & - & - & + & + & + & + & - & + & $\mathrm{w}$ & + & - & - & - & + & + & - & $\mathrm{w}$ & - & - \\
\hline S. delphini & P6070 & penguin & Antarctica & - & - & - & + & + & + & - & + & - & + & - & - & - & + & + & - & $\mathrm{w}$ & - & - \\
\hline S. delphini & P6456 & penguin & Antarctica & $\mathrm{w}$ & - & + & - & + & + & - & w & $\mathrm{w}$ & - & - & - & - & $\mathrm{w}$ & + & - & - & - & - \\
\hline S. delphini & P12456 & camel & France & $\mathrm{w}$ & $\mathrm{w}$ & + & - & + & + & - & - & + & + & - & $\mathrm{w}$ & - & + & + & + & $\mathrm{w}$ & + & - \\
\hline S. delphini & P12457 & horse & UK & + & $\mathrm{w}$ & + & - & + & + & - & - & $\mathrm{w}$ & + & + & - & - & $\mathrm{w}$ & + & + & $\mathrm{w}$ & $\mathrm{w}$ & $\mathrm{w}$ \\
\hline S. delphini & P12458 & horse & UK & $\mathrm{w}$ & $\mathrm{w}$ & + & + & + & + & - & + & $\mathrm{w}$ & $\mathrm{w}$ & - & - & - & + & + & - & - & $\mathrm{w}$ & - \\
\hline S. delphini & CCM 2618 & $\operatorname{mink}$ & Czechia & + & - & + & + & + & + & - & + & + & + & - & - & - & + & + & - & $\mathrm{w}$ & - & $\mathrm{w}$ \\
\hline S. delphini & P12548 & $\operatorname{mink}$ & Denmark & $\mathrm{w}$ & - & + & - & + & + & - & + & $\mathrm{w}$ & - & - & - & - & + & + & - & $\mathrm{w}$ & - & $\mathrm{w}$ \\
\hline S. delphini & P12549 & $\operatorname{mink}$ & Denmark & $\mathrm{w}$ & - & + & + & + & + & + & + & $\mathrm{w}$ & + & - & - & - & + & + & - & $\mathrm{w}$ & - & - \\
\hline S. delphini & P12550 & $\operatorname{mink}$ & Denmark & $\mathrm{w}$ & $\mathrm{w}$ & + & + & + & + & - & + & $\mathrm{w}$ & + & - & - & - & + & + & - & $\mathrm{w}$ & - & $\mathrm{w}$ \\
\hline S. delphini & CCM 8998 & human & USA & + & + & + & + & + & - & - & + & $\mathrm{w}$ & + & - & - & - & + & + & - & + & - & - \\
\hline S.pseudintermedius & CCM $7315^{\mathrm{T}}$ & cat & Belgium & + & + & + & - & + & - & - & + & + & + & - & - & $\mathrm{w}$ & + & + & - & + & - & - \\
\hline S. pseudintermedius & P7945 & seal & Antarctica & $\mathrm{w}$ & $\mathrm{w}$ & + & - & + & + & - & - & $\mathrm{w}$ & - & - & - & - & + & + & - & - & - & - \\
\hline S. pseudintermedius & P8480 & seal & Antarctica & + & - & + & - & + & + & - & + & + & - & - & - & $\mathrm{w}$ & + & + & - & $\mathrm{w}$ & - & - \\
\hline S. pseudintermedius & P8688 & seal & Antarctica & + & - & + & - & + & + & - & - & $\mathrm{w}$ & - & - & - & - & + & + & - & - & $\mathrm{w}$ & - \\
\hline S. pseudintermedius & P8720 & seal & Antarctica & $\mathrm{w}$ & + & + & - & + & + & - & - & $\mathrm{w}$ & - & - & - & - & + & + & - & - & - & - \\
\hline S. pseudintermedius & P8807 & seal & Antarctica & + & + & + & - & + & + & - & $\mathrm{w}$ & + & - & - & - & $\mathrm{w}$ & + & + & - & $\mathrm{w}$ & - & - \\
\hline S. pseudintermedius & P9111 & seal & Antarctica & + & $\mathrm{w}$ & + & - & + & + & - & w & + & + & - & - & $\mathrm{w}$ & + & + & - & $\mathrm{w}$ & - & - \\
\hline S. pseudintermedius & P12459 & seal & Antarctica & $\mathrm{w}$ & - & + & - & + & + & - & + & $\mathrm{w}$ & - & - & - & $\mathrm{w}$ & + & + & - & - & - & - \\
\hline S. pseudintermedius & P12460 & seal & Antarctica & - & $\mathrm{w}$ & + & - & + & + & - & + & $\mathrm{w}$ & + & - & - & $\mathrm{w}$ & + & + & - & + & - & - \\
\hline S. pseudintermedius & P12461 & seal & Antarctica & $\mathrm{w}$ & $\mathrm{w}$ & + & - & + & + & - & + & + & - & - & - & $\mathrm{w}$ & + & + & - & + & - & - \\
\hline S. pseudintermedius & P12462 & seal & Antarctica & - & - & + & - & + & + & - & + & + & + & - & - & $\mathrm{w}$ & + & + & - & + & - & - \\
\hline S. pseudintermedius & P12463 & seal & Antarctica & - & $\mathrm{w}$ & + & - & + & + & - & + & + & - & - & - & $\mathrm{w}$ & + & + & - & + & - & - \\
\hline S. pseudintermedius & P12464 & seal & Antarctica & - & $\mathrm{w}$ & + & - & + & + & - & + & + & + & - & - & $\mathrm{w}$ & + & + & - & + & - & - \\
\hline S. pseudintermedius & P12465 & seal & Antarctica & $\mathrm{w}$ & $\mathrm{w}$ & + & - & + & + & - & + & + & - & - & - & - & + & + & - & + & - & - \\
\hline S. pseudintermedius & P12466 & seal & Antarctica & $\mathrm{w}$ & $\mathrm{w}$ & + & - & + & + & - & w & + & + & - & - & $\mathrm{w}$ & + & + & - & + & - & - \\
\hline S. pseudintermedius & P12467 & seal & Antarctica & + & $\mathrm{w}$ & + & - & + & + & - & + & + & - & - & - & $\mathrm{w}$ & + & + & - & - & - & - \\
\hline S. pseudintermedius & P10574 & seal & Antarctica & - & + & + & - & + & + & - & - & $\mathrm{w}$ & - & - & - & - & + & + & - & - & - & - \\
\hline S. intermedius & CCM $5739^{\mathrm{T}}$ & pigeon & Czechia & $\mathrm{w}$ & - & + & - & + & + & - & + & $\mathrm{w}$ & + & - & - & $\mathrm{w}$ & + & + & + & $\mathrm{w}$ & - & - \\
\hline S. cornubiensis & CCM $8997^{\mathrm{T}}$ & human & UK & + & + & + & + & + & + & + & + & + & + & - & - & - & + & + & - & + & - & - \\
\hline
\end{tabular}

Legend: COA, coagulase; ARG, arginine dihydrolase; URE, urease; TWE, hydrolysis of Tween 80; GEL, hydrolysis of gelatin; Cas, hydrolysis of casein; E-Y, egg-yolk reaction (lecithinase);

C45, growth at $45^{\circ} \mathrm{C}$; GLY, acid from glycerol; MAN, acid from mannitol; SOR, acid from sorbitol; ARB, acid from arbutin; MDG, acid from $\alpha$-methyl-D-glucoside; LAC, acid from lactose;

TRE, acid from trehalose; GEN, acid from $\beta$-gentiobiose; TUR, acid from turanose; N-PH, naphthol-AS-BI-phosphohydrolase; $\alpha$-FU, $\alpha$-fucosidase; +, positive; -, negative; W, weak. 
Table 2. Proposal of phenotypic traits suitable for differentiation of Staphylococcus intermedius group species.

\begin{tabular}{cccccc}
\hline Species & Strains & TWE & E-Y & MAN & MDG \\
\hline S. delphini & 16 strains & $\mathrm{d}(63 \%)$ & $-(6 \%)$ & $+(88 \%)$ & $-(0 \%)$ \\
S. pseudintermedius & 17 strains & $-(0 \%)$ & $-(0 \%)$ & $(-)(29 \%)$ & $(+)(71 \%)$ \\
S. intermedius & CCM $5739^{\mathrm{T}}$ & - & - & + & $\mathrm{W}$ \\
S. cornubiensis & CCM $8997^{\mathrm{T}}$ & + & + & + & - \\
\hline
\end{tabular}

Legend: TWE, hydrolysis of Tween 80; E-Y, egg-yolk reaction (lecithinase); MAN, acid from mannitol; MDG, acid from $\alpha$-methyl-D-glucoside;,$+ 85 \%$ to $100 \%$; $(+), 70 \%$ to $84 \%$; d, $31 \%$ to $69 \% ;(-), 15 \%$ to $29 \%$;,$- 0 \%$ to $14 \%$; w, weak.

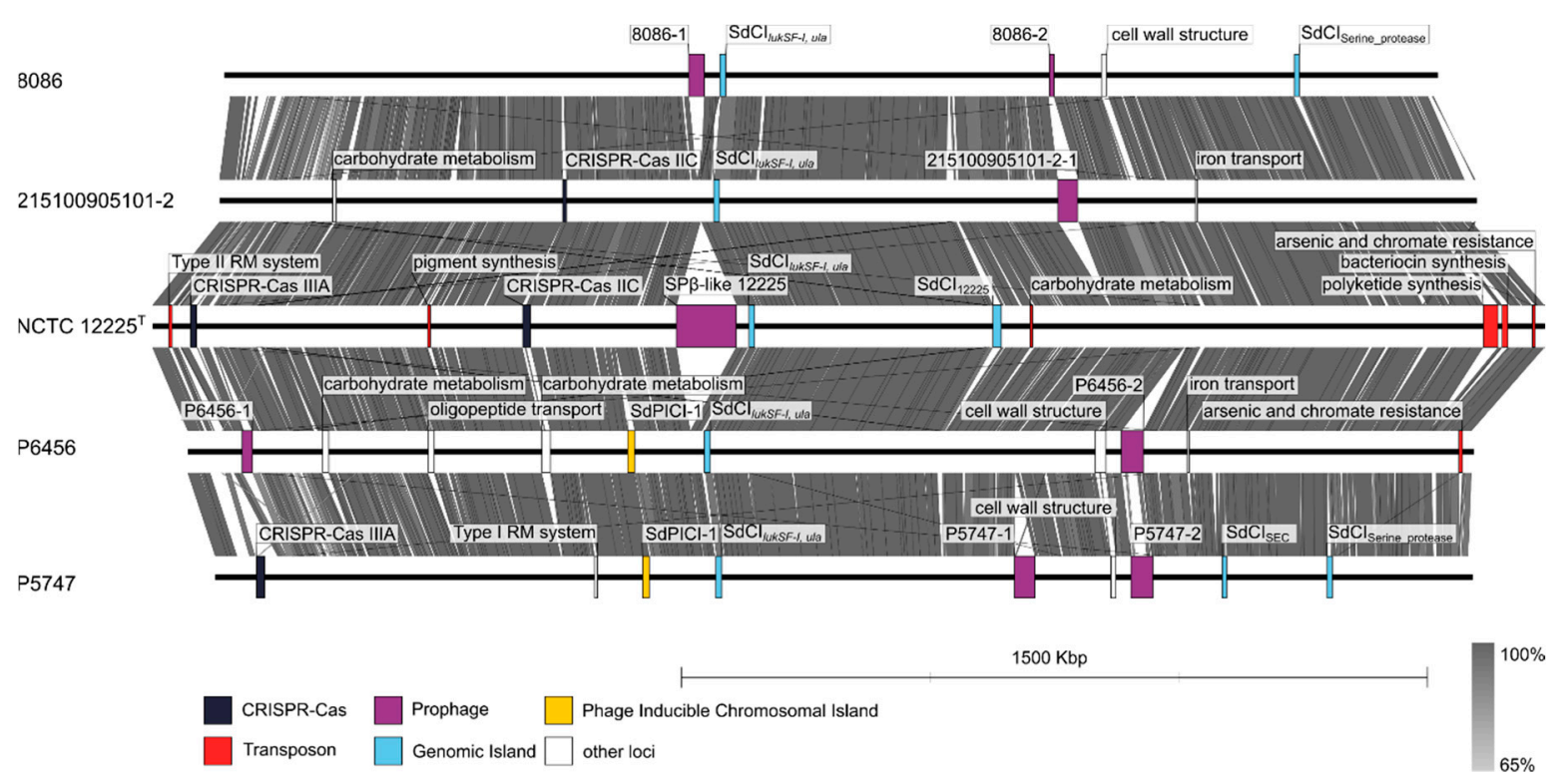

Figure 5. Whole-genome comparison of Staphylococcus delphini penguin isolates P5747 (GenBank accession no. WNLD00000000) and P6456 (WNLE00000000) with horse strains 8086 (CAIA00000000), 215100905101-2 (MWUT00000000), and type strain NCTC $12225^{\mathrm{T}}$ from a dolphin (LR134263). Genomic regions with major differences between neighboring genomes and significant mobile genetic elements are highlighted in rectangles and are color-coded according to the legend. Prophage genomes 8086-1, 8086-2, and P6456-1 were located on different contigs, and therefore are not complete in the whole-genome comparison. Conserved regions with more than $65 \%$ homology are indicated with different shades of grey as determined by blastn.

Variability in S. delphini genome structure is mostly associated with mobile genetic elements and numerous genomic islets (Table S2 and Figure 5). The genomes of S. delphini strains P5747 and P6456 contain predicted plasmid contigs, prophages, a novel S. delphini phage-inducible chromosomal island (PICI) designated SdPICI-1 inserted between the chaperone GroEL and glucosamine-6-phosphate $\mathrm{N}$-acetyltransferase genes, and genomic island designated $\mathrm{SdCI}_{\mathrm{SEC}}$ encoding staphylococcal enterotoxin C (SEC) and putative proteins involved in its transfer. Staphylococcus delphini strain P5747 harbours CRISPR type IIIA, a distinctive gene cluster for purine metabolism, genes encoding sphingomyelinase $C$, sialidase B, putative genes for capsular polysaccharide synthesis located near the oriC region, and trypsin-like serine protease gene cluster. A genomic island containing bi-component leukocidin locus lukSF-I and the L-ascorbate transport and utilization ( $u l a)$ operon was observed in all the analyzed genomes. The genome of S. delphini strain P6456 contains a gene for a novel exfoliative toxin (locus tag: FMF08_11915) in the oriC environ, gene clusters for the intake and metabolism of saccharides and oligopeptides, and a composite transposon for arsenic and chromate resistance.

The genes for virulence factors, surface and extracellular proteins are dispersed throughout $S$. delphini genomes. Majority of these proteins have similar distribution to other SIG members (Table S3). 
The comparative analysis showed three major differences in those proteins from S. delphini strains and representative SIG members originating from different hosts as follows: (i) variability of serine proteases including exfoliative toxin-like proteins, (ii) different polysaccharide capsule synthesis proteins, and (iii) extensive variability of putative proteins with unknown function containing a LPXTG motif anchoring to cell wall peptidoglycan (Table S3).

To evaluate the intergenomic distances between the $S$. delphini genomes, ANI and dDDH values were determined (Table 3). The calculated ANI values among analyzed S. delphini genomes ranged from $96.28 \%$ to $98.66 \%$, and unambiguously confirmed the position of both strains P5747 and P6456 as $S$. delphini species and at the same time showed that $S$. pseudintermedius and $S$. intermedius type strains are well below the thresholds of $95 \%$ to $96 \%$ for species delineation [62]. The calculated dDDH values among S. delphini were relatively low and indicated an extensive variability that could represent specialization to specific hosts. As a further extension to genome-based phylogeny the Up-to-date Bacterial Core Gene (UBCG) tool was used to compare 92 core genes among analyzed S. delphini genomes (Figure 6). This analysis confirmed that the strains do not divide to distinctive lineages according to their animal host.

Table 3. Intergenomic distances between the genomes of Staphylococcus intermedius group strains in percent, represented by average nucleotide identity (ANI) and digitally derived genome-to-genome distances (GGD) emulating DNA-DNA hybridization values.

\begin{tabular}{|c|c|c|c|c|c|c|c|c|c|c|c|c|c|c|c|c|}
\hline \multirow[t]{2}{*}{ Strain } & \multicolumn{2}{|l|}{ P5747 } & \multicolumn{2}{|l|}{ P6456 } & \multicolumn{2}{|c|}{$\begin{array}{l}\text { NCTC } \\
12225^{T}\end{array}$} & \multicolumn{2}{|c|}{$215100905101-2$} & \multicolumn{2}{|l|}{8086} & \multicolumn{2}{|l|}{$\begin{array}{l}\text { NCTC } \\
11048^{T}\end{array}$} & \multicolumn{2}{|c|}{ LMG $22219^{\mathrm{T}}$} & \multicolumn{2}{|l|}{$\mathrm{NW1}^{\mathrm{T}}$} \\
\hline & GGD & ANI & GGD & ANI & GGD & ANI & GGD & ANI & GGD & ANI & GGD & ANI & GGD & ANI & GGD & ANI \\
\hline S. delphini P5747 & - & - & 70.2 & 96.3 & 70.5 & 96.5 & 77.4 & 97.6 & 85.6 & 98.4 & 35.8 & 88.6 & 55.1 & 93.9 & 33.5 & 87.4 \\
\hline S. delphini NCTC $12225^{\mathrm{T}}$ & 70.5 & 96.5 & 87.5 & 98.7 & - & - & 70.4 & 96.6 & 70.1 & 96.4 & 35.9 & 88.6 & 51.2 & 93.1 & 33.5 & 87.4 \\
\hline S. delphini $215100905101-2$ & 77.4 & 97.6 & 69.5 & 96.3 & 70.4 & 96.6 & - & - & 78.4 & 97.6 & 35.7 & 88.6 & 54.7 & 93.7 & 33.6 & 87.8 \\
\hline S. delphini 8086 & 85.6 & 98.4 & 69.0 & 96.3 & 70.1 & 96.4 & 78.4 & 97.6 & - & - & 35.6 & 88.6 & 54.9 & 93.9 & 33.6 & 87.5 \\
\hline S. intermedius $\mathrm{NCTC} 11048^{\mathrm{T}}$ & 35.8 & 88.6 & 35.5 & 88.4 & 35.9 & 88.6 & 35.7 & 88.6 & 35.6 & 88.7 & - & - & 34.9 & 88.0 & 36.2 & 88.6 \\
\hline
\end{tabular}

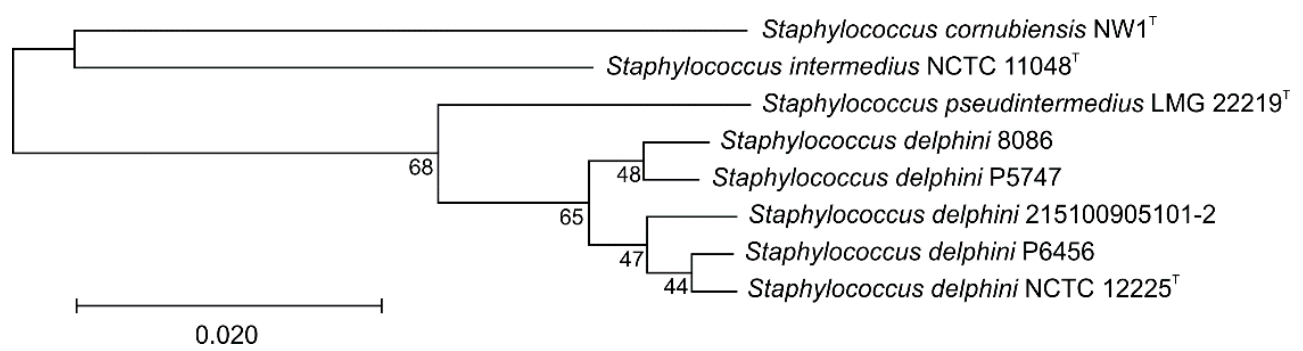

Figure 6. Core gene set phylogenetic tree of Staphylococcus delphini strains from different animals (penguin isolates P5747 and P6456, horse strains 8086 and 215100905101-2, and a dolphin strain NCTC $12225^{\mathrm{T}}$ ). The phylogenetic tree was constructed using Up-to-date bacterial core gene set (UBCG) concatenated alignment of 92 core genes. A total of 86,031 nucleotide positions were used. Maximum likelihood phylogenetic tree was inferred using Fasttree version 2.1.10 using GTR + CAT model. Gene support indices are given at branching points (maximal possible value is 92). Bar, 0.1 substitution per position.

\section{Discussion}

The analyzed SIG strains were collected in several consecutive years at three different locations. Species identification based on previously evaluated 16S ribosomal DNA-based identification [63] showed the presence of 16 staphylococcal taxa. Some of the recently described staphylococcal species shared high similarity in their $16 \mathrm{~S}$ rRNA sequence and were distinguished on the basis of whole-genome sequencing, therefore they are identified as species complexes. Among the most prevalent staphylococcal species isolated from Antarctic wildlife were S. haemolyticus, S. epidermidis, and S. sciuri, which have been previously collected in Antarctic environmental samples [4-6,64]. 
In this study, several strains of $S$. aureus were also collected, which corresponds with the findings of Van Elk et al. [65], who recovered an S. aureus isolate from Antarctic southern elephant seal and suggested that it could be a host species-specific and coevolved variant which is not closely related to S. aureus strains from terrestrial species, based on MLST analysis.

To the best of our knowledge, this is the first report of the isolation and characterization of S. delphini and S. pseudintermedius from Antarctic animals, penguins and seals. SIG species, thus, seem to be ubiquitous and the most common coagulase-positive staphylococci recovered from non-human animals, in which they can act as opportunistic pathogens and cause a variety of infections. Staphylococcus delphini has been previously isolated from a broad range of phylogenetically unrelated mammals (dolphins, cows, horses, camels, and mustelids). The isolation of S. delphini from the Antarctic Adélie penguin is the only report from birds except for rare isolates from pigeons [12]. S. pseudintermedius is a predominant opportunistic pathogen of canine hosts, and the clonal diversity and broad geographic distribution of S. pseudintermedius suggests that it has coevolved with the suborder Caniformia ("dog-like" carnivorans) for a long time in evolutionary terms [11,66,67]. Aarestrup [67] isolated SIG strains from the skin of healthy members of six phylogenetic groups within Caniformia, but not successfully from the seal family (Phocidae). The report of the occurrence of S. pseudintermedius in Weddell seals supports the theory of $S$. pseudintermedius coevolution with Caniformia, and it is evident that the bacteria can coexist with their hosts in the extreme polar environment. It is likely that SIG species shared a common ancestor and evolved with their specific host adaptation, analogously to the relationship between $S$. aureus and its sister primate-associated species Staphylococcus simiae [68,69] or Staphylococcus schweitzeri [70]. In addition, this study concluded that members of SIG are distributed worldwide and inhabit an even wider range of hosts than was previously thought.

Differentiating between species belonging to SIG is problematic. In addition, some strains previously described as S. intermedius have been reassigned to other species within SIG [12,71]. Identification based on conventional biochemical, physiological, and growth tests in a routine microbiology laboratory is difficult, since SIG members share many phenotypic characteristics, the expression of many biochemical properties is variable, and taxonomic descriptions were done with various identification sets utilizing different reaction substrates. We evaluated the performance of molecular-based and phenotype-based techniques for the ability to differentiate and identify members of SIG, including Antarctic isolates. The study demonstrated that $r p o B$ gene sequencing and rep-PCR gave consistent results and differentiated the isolates into distinctive clusters corresponding to individual species within SIG. Cluster analysis based on MALDI-TOF MS protein data was able to separate the S. pseudintermedius and S. delphini Antarctic isolates, place them together with corresponding type strains, and create separate clusters from S. intermedius and S. cornubiensis type strains. Unlike a recent report [72], mass spectrometry was unable to identify two Antarctic isolates of S. delphini using a MALDI-TOF MS-based scoring identification workflow.

The Antarctic S. delphini and S. pseudintermedius isolates phenotypically differ from both the type and used reference strains. The type strain of $S$. delphini is described as negative for trehalose and thermonuclease. Because the species description of $S$. delphini was based on only two strains, in our study we tested a set of Antarctic isolates supplemented with $S$. delphini reference strains from different animals, including a human isolate. All Antarctic S. delphini strains were positive for acid production from trehalose, similarly to Sasaki et al. [12] who also reported some S. delphini strains to be positive for trehalose and thermonuclease. Moreover, in our study we found positive gelatinase activity among $S$. delphini isolates and reference strains, which contradicted their species description, as well as lecithinase production, which was positive for the type strain but negative for the tested strains. It is possible that strains from diverse animals represent distinctive ecotypes with specific ecological adaptations. Variation in phenotype, borderline dDDH values between strains (Table 3), and previously reported polymorphisms in housekeeping genes [12] suggest that more subspecies exists within $S$. delphini species. 
Similar to S. aureus [73,74], the major differences in the S. delphini genomes are due to variable genetic elements. Various prophages with low similarity to known phage sequences in available databases were found in all strains. Two different types of wall teichoic acids synthesis loci were found in the analyzed genomes. Since wall teichoic acids serve as receptors for bacteriophage adsorption [74] and the phage adsorption is sufficient for efficient transduction [75] we hypothesize that differences in phage receptors can drive the diversification of $S$. delphini genomes. The staphylococcal cassette chromosome mec, which was described in methicillin-resistant S. pseudintermedius [76], was not detected in any of the analyzed S. delphini genomes. The presence of CRISPR/Cas and the type of cas genes was not related to the animal source of the isolation, thus the loci could have been acquired independently. Staphylococcus aureus pathogenicity islands (SaPI) are well described representatives of PICI and contribute to horizontal gene transfer [77]. In contrast to SaPI, S. delphini PICI SdPICI-1 was only observed in strains isolated from penguins and contained genes for phage-related head structural proteins and both terminase subunits, which has been observed in some PICIs of Gram-negative bacteria [78]. The finding of genomic island harboring leukocidin encoding genes lukFS-I among all analyzed strains confirms its ancient origin [25] and also its preservation among S. delphini strains in the polar environment. Virulence potential of all analyzed S. delphini strains is enhanced by the presence of SEC encoding genes, which have been previously detected in S. pseudintermedius isolates and associated with canine pyoderma $[79,80]$. Distribution of other toxin genes is variable among the strains (Table S3). Putative exfoliative toxin from P6456 strain has 53\% amino acid identity with S. pseudintermedius exfoliative toxins EXI and ExpB [81,82]. Furthermore, an island with multiple paralog genes encoding trypsin-like serine proteases related to exfoliative toxins [83] was found in strain P5747 (Figure 5 and Table S3), being a possible virulence factor.

Staphylococcus delphini genomes of the type strain, the strains representing two different phylogenetic branches of equine origin and the selected genomes of SIG isolates from other animals, were used for the comparative genomic analysis with focus on virulence, cell wall anchored proteins, and extracellular proteins (Table S3). These proteins most likely play a role in adaptation to the host and in a defence against host immunity. Homologs of $S$. delphini surface proteins were found in other SIG species, but many proteins were strain-specific, suggesting specific adaptation and virulence. However, there was no distinctive pattern of surface proteins corresponding to individual animal hosts. The location of these genes for surface proteins was predominantly on the chromosomes and not on the mobile genetic elements indicating both common ancestry and differential gene loss among strains as well as gene gain via horizontal transfer events. Despite numerous putative virulence factors found in analyzed genomes of $S$. delphini, further studies are needed to consider their role in animal pathogenesis or the possible risk of zoonotic infection to humans.

\section{Emended Description of Staphylococcus delphini (Varaldo et al., 1988)}

The description is based on the original description and observations of six isolates from penguins and eight reference strains from animals and human (Table 1). The morphological, biochemical, and physiological characteristics are generally those of the S. delphini description [15] with the exception of gelatin and lecithin hydrolysis and trehalose acidification, which were strain dependent. In contrast to type strain CCM 4115 ${ }^{\mathrm{T}}$ and reference strain CCM 4184, both from dolphins [15], all the studied S. delphini strains were gelatinase positive, but lecithinase negative and produced acid from trehalose. Below are the mentioned emended positive and negative test results not included in the original description.

Acid is produced from glycerol, ribose, galactose, and N-acetyl-glucosamine (API $50 \mathrm{CH}$ ). Esterase (C4), esterase-lipase (C8), acid phosphatase, pyrrolidonyl arylamidase, leucine arylamidase, and $\beta$-galactosidase positive (API ZYM). Resistant to bacitracin (0.04 U) and susceptible to furazolidone $(100 \mu \mathrm{g})$. Negative oxidase, ornithine decarboxylase, esculin and starch hydrolysis, and growth at $20^{\circ} \mathrm{C}$. Acid production is negative from erythritol, D-arabinose, D-xylose, adonitol, $\beta$-methyl-D-xyloside, sorbose, rhamnose, dulcitol, inositol, sorbitol, $\alpha$-methyl-D-mannoside, $\alpha$-methyl-D-glucoside, amygdalin, arbutin, salicine, cellobiose, melibiose, inulin, melezitose, raffinose, starch, glycogen, 
D-lyxose, D-tagatose, D-fucose, L-fucose, D-arabitol, L-arabitol, gluconate, 2-keto-gluconate, and 5-keto-gluconate (API $50 \mathrm{CH}$ ). No enzymatic activity found for lipase (C14), valine arylamidase, cystine arylamidase, trypsin, $\alpha$-chymotrypsin, $\alpha$-galactosidase, $\beta$-glucuronidase, $\alpha$-glucosidase, $\beta$-glucosidase, $\mathrm{N}$-acetyl- $\beta$-glucosaminidase, and $\alpha$-mannosidase (API ZYM). Variable reactions are shown in Table 1. Isolated from mucous membranes of different animals, occasionally humans. $\mathrm{G}+\mathrm{C}$ content of $38 \mathrm{~mol} \%$ calculated from whole genomic sequence.

Supplementary Materials: The following are available online at http://www.mdpi.com/2076-2607/8/2/204/s1: Table S1: Staphylococcus spp. strains identified in animal-related samples from James Ross Island and Seymour Island, Antarctica, Table S2: Comparison of selected genomic features of Staphylococcus delphini strains P5747 and P6456 from penguins, and S. delphini strains from other hosts, Table S3: Distribution of virulence factors, surface and extracellular proteins among the Staphylococcus delphini strains from different hosts and from the reference and type strains of other SIG species.

Author Contributions: Design of the study and conceptualization, R.P., I.S., and V.V.; sampling, isolation and preliminarily identification of the strains, I.S. and M.L.; performance of experiments and investigations, V.V., I.S., P.Š., and O.Š.; analysis of data, V.V., I.S., M.Z., P.Š., V.K., and R.P.; writing-original draft preparation, V.V., M.Z., and I.S.; writing-review and editing, V.V., R.P., I.S., P.Š., and J.D.; visualization, M.Z., P.Š., V.K., and R.P.; supervision, R.P.; funding acquisition, R.P., I.S., and J.D. All authors have read and agreed to the published version of the manuscript.

Funding: This work was supported by the Ministry of Education, Youth and Sports of the Czech Republic (MEYS CR) (grant number LM2015078) and by the Ministry of Health of the Czech Republic (grant number 16-29916A to R.P.). The CIISB research infrastructure project (LM2018127), the NCMG research infrastructure project (LM2015091) and the project CEITEC 2020 (LQ1601) funded by MEYS CR, are gratefully acknowledged for the financial support of the MALDI-TOF MS measurements at the Proteomics Core Facility and whole-genome sequencing at the Genomics Core Facility of CEITEC. Students participating in this work were supported by the Grant Agency of Masaryk University (MUNI/A/1127/2019 to J.D.).

Acknowledgments: We are grateful for the scientific infrastructure of the J.G. Mendel Czech Antarctic Station as part of the Czech Polar Research Infrastructure (CzechPolar2) and to its crew for their assistance, as well as to the Czech Antarctic Foundation for their support. We wish to thank Eva Staňková and Jana Bajerová (Czech Collection of Microorganisms, Masaryk University) and Tereza Gelbíčová (Veterinary Research Institute, Brno) for technical assistance. Prof. J. Ross Fitzgerald (University of Edinburgh, UK), Dr. Nanett K. Nikolaisen (Technical University of Denmark, Denmark), and Dr. Stephen A. Kania (University of Tennessee, USA) are gratefully acknowledged for providing us with bacterial strains.

Conflicts of Interest: The authors declare no conflicts of interest.

\section{References}

1. Götz, F.; Bannerman, T.; Schleifer, K.-H. The Genera Staphylococcus and Macrococcus. In The Prokaryotes. Volume 4: Bacteria: Firmicutes, Cyanobacteria; Dworkin, M., Falkow, S., Rosenberg, E., Schleifer, K.-H., Stackebrandt, E., Eds.; Springer Science: New York, NY, USA, 2006; Volume 4, pp. 5-75.

2. Pantůček, R.; Sedláček, I.; Indráková, A.; Vrbovská, V.; Mašlaňová, I.; Kovařovic, V.; Švec, P.; Králová, S.; Krištofová, L.; Kekláková, J.; et al. Staphylococcus edaphicus sp. nov., isolated in Antarctica, harbors the mecC gene and genomic islands with a suspected role in adaptation to extreme environments. Appl. Env. Microbiol. 2018, 84. [CrossRef]

3. Shivaji, S.; Begum, Z.; Shiva Nageswara Rao, S.S.; Vishnu Vardhan Reddy, P.V.; Manasa, P.; Sailaja, B.; Prathiba, M.S.; Thamban, M.; Krishnan, K.P.; Singh, S.M.; et al. Antarctic ice core samples: Culturable bacterial diversity. Res. Microbiol. 2013, 164, 70-82. [CrossRef] [PubMed]

4. Peeters, K.; Hodgson, D.A.; Convey, P.; Willems, A. Culturable diversity of heterotrophic bacteria in Forlidas Pond (Pensacola Mountains) and Lundstrom Lake (Shackleton Range), Antarctica. Microbiol. Ecol. 2011, 62, 399-413. [CrossRef] [PubMed]

5. Arenas, F.A.; Pugin, B.; Henriquez, N.A.; Arenas-Salinas, M.A.; Diaz-Vasquez, W.A.; Pozo, M.F.; Munoz, C.M.; Chasteen, T.G.; Perez-Donoso, J.M.; Vasquez, C.C. Isolation, identification and characterization of highly tellurite-resistant, tellurite-reducing bacteria from Antarctica. Polar Sci. 2014, 8, 40-52. [CrossRef]

6. Leiva, S.; Alvarado, P.; Huang, Y.; Wang, J.; Garrido, I. Diversity of pigmented Gram-positive bacteria associated with marine macroalgae from Antarctica. FEMS Microbiol. Lett. 2015, 362, fnv206. [CrossRef] [PubMed] 
7. Sieburth, J.M. Gastrointestinal microflora of Antarctic birds. J. Bacteriol. 1959, 77, 521-531. [CrossRef] [PubMed]

8. Vazquez, S.C.; Merino, L.N.R.; Maccormack, W.P.; Fraile, E.R. Protease-producing psychrotrophic bacteria isolated from Antarctica. Polar Biol. 1995, 15, 131-135. [CrossRef]

9. Nievas, V.F.; Leotta, G.A.; Vigo, G.B. Subcutaneous clostridial infection in Adelie penguins in Hope Bay, Antarctica. Polar Biol. 2007, 30, 249-252. [CrossRef]

10. Mellish, J.; Tuomi, P.; Hindle, A.; Jang, S.; Horning, M. Skin microbial flora and effectiveness of aseptic technique for deep muscle biopsies in Weddell seals (Leptonychotes weddellii) in McMurdo Sound, Antarctica. J. Wildlife Dis. 2010, 46, 655-658. [CrossRef]

11. Bannoehr, J.; Ben Zakour, N.L.; Waller, A.S.; Guardabassi, L.; Thoday, K.L.; van den Broek, A.H.M.; Fitzgerald, J.R. Population genetic structure of the Staphylococcus intermedius group: Insights into agr diversification and the emergence of methicillin-resistant strains. J. Bacteriol. 2007, 189, 8685-8692. [CrossRef]

12. Sasaki, T.; Kikuchi, K.; Tanaka, Y.; Takahashi, N.; Kamata, S.; Hiramatsu, K. Reclassification of phenotypically identified Staphylococcus intermedius strains. J. Clin. Microbiol. 2007, 45, 2770-2778. [CrossRef] [PubMed]

13. Hájek, V. Staphylococcus intermedius, a new species isolated from animals. Int. J. Syst. Bacteriol. 1976, 26, 401-408. [CrossRef]

14. Devriese, L.A.; Vancanneyt, M.; Baele, M.; Vaneechoutte, M.; De Graef, E.; Snauwaert, C.; Cleenwerck, I.; Dawyndt, P.; Swings, J.; Decostere, A.; et al. Staphylococcus pseudintermedius sp. nov., a coagulase-positive species from animals. Int. J. Syst. Evol. Microbiol. 2005, 55, 1569-1573. [CrossRef] [PubMed]

15. Varaldo, P.E.; Kilpperbalz, R.; Biavasco, F.; Satta, G.; Schleifer, K.H. Staphylococcus delphini sp. nov., a coagulase-positive species isolated from dolphins. Int. J. Syst. Bacteriol. 1988, 38, 436-439. [CrossRef]

16. Murray, A.K.; Lee, J.; Bendall, R.; Zhang, L.; Sunde, M.; Schau Slettemeas, J.; Gaze, W.; Page, A.J.; Vos, M. Staphylococcus cornubiensis sp. nov., a member of the Staphylococcus intermedius group (SIG). Int. J. Syst. Evol. Microbiol. 2018, 68, 3404-3408. [CrossRef]

17. Bond, R.; Loeffler, A. What's happened to Staphylococcus intermedius? Taxonomic revision and emergence of multi-drug resistance. J. Small Anim. Pr. 2012, 53, 147-154. [CrossRef]

18. Viau, R.; Hujer, A.M.; Hujer, K.M.; Bonomo, R.A.; Jump, R.L.P. Are Staphylococcus intermedius infections in humans cases of mistaken identity? A case series and literature review. Open Forum Infect. Dis. 2015, 2, ofv110. [CrossRef]

19. Decristophoris, P.; Fasola, A.; Benagli, C.; Tonolla, M.; Petrini, O. Identification of Staphylococcus intermedius group by MALDI-TOF MS. Syst. Appl. Microbiol. 2011, 34, 45-51. [CrossRef]

20. Murugaiyan, J.; Walther, B.; Stamm, I.; Abou-Elnaga, Y.; Brueggemann-Schwarze, S.; Vincze, S.; Wieler, L.H.; Lubke-Becker, A.; Semmler, T.; Roesler, U. Species differentiation within the Staphylococcus intermedius group using a refined MALDI-TOF MS database. Clin. Microbiol. Infect. 2014, 20, 1007-1014. [CrossRef]

21. Sasaki, T.; Tsubakishita, S.; Tanaka, Y.; Sakusabe, A.; Ohtsuka, M.; Hirotaki, S.; Kawakami, T.; Fukata, T.; Hiramatsu, K. Multiplex-PCR method for species identification of coagulase-positive staphylococci. J. Clin. Microbiol. 2010, 48, 765-769. [CrossRef]

22. Lee, J.; Murray, A.; Bendall, R.; Gaze, W.; Zhang, L.H.; Vos, M. Improved detection of Staphylococcus intermedius group in a routine diagnostic laboratory. J. Clin. Microbiol. 2015, 53, 961-963. [CrossRef] [PubMed]

23. Slettemeas, J.S.; Mikalsen, J.; Sunde, M. Further diversity of the Staphylococcus intermedius group and heterogeneity in the $\mathrm{MboI}$ restriction site used for Staphylococcus pseudintermedius species identification. J. Vet. Diagn. Invest. 2010, 22, 756-759. [CrossRef] [PubMed]

24. Solyman, S.M.; Black, C.C.; Duim, B.; Perreten, V.; van Duijkeren, E.; Wagenaar, J.A.; Eberlein, L.C.; Sadeghi, L.N.; Videla, R.; Bemis, D.A.; et al. Multilocus sequence typing for characterization of Staphylococcus pseudintermedius. J. Clin. Microbiol. 2013, 51, 306-310. [CrossRef] [PubMed]

25. Ben Zakour, N.L.; Beatson, S.A.; van den Broek, A.H.M.; Thoday, K.L.; Fitzgerald, J.R. Comparative genomics of the Staphylococcus intermedius group of animal pathogens. Front. Cell. Infect. Microbiol. 2012, 2, 44. [CrossRef] [PubMed]

26. Verstappen, K.M.; Huijbregts, L.; Spaninks, M.; Wagenaar, J.A.; Fluit, A.C.; Duim, B. Development of a real-time PCR for detection of Staphylococcus pseudintermedius using a novel automated comparison of whole-genome sequences. PLoS ONE 2017, 12, e0189520. [CrossRef] 
27. Bannoehr, J.; Franco, A.; Iurescia, M.; Battisti, A.; Fitzgerald, J.R. Molecular diagnostic identification of Staphylococcus pseudintermedius. J. Clin. Microbiol. 2009, 47, 469-471. [CrossRef] [PubMed]

28. Borjesson, S.; Gomez-Sanz, E.; Ekstrom, K.; Torres, C.; Gronlund, U. Staphylococcus pseudintermedius can be misdiagnosed as Staphylococcus aureus in humans with dog bite wounds. Eur. J. Clin. Microbiol. 2015, 34, 839-844. [CrossRef]

29. Lainhart, W.; Yarbrough, M.L.; Burnham, C.A. The brief case: Staphylococcus intermedius group-look what the dog dragged in. J. Clin. Microbiol. 2018, 56, e00839-17. [CrossRef]

30. Hanselman, B.A.; Kruth, S.A.; Rousseau, J.; Weese, J.S. Coagulase positive staphylococcal colonization of humans and their household pets. Can. Vet. J. 2009, 50, 954-958.

31. Ishihara, K.; Shimokubo, N.; Sakagami, A.; Ueno, H.; Muramatsu, Y.; Kadosawa, T.; Yanagisawa, C.; Hanaki, H.; Nakajima, C.; Suzuki, Y.; et al. Occurrence and molecular characteristics of methicillin-resistant Staphylococcus aureus and methicillin-resistant Staphylococcus pseudintermedius in an academic veterinary hospital. Appl. Env. Microbiol. 2010, 76, 5165-5174. [CrossRef]

32. Sasaki, T.; Kikuchi, K.; Tanaka, Y.; Takahashi, N.; Kamata, S.; Hiramatsu, K. Methicillin-resistant Staphylococcus pseudintermedius in a veterinary teaching hospital. J. Clin. Microbiol. 2007, 45, 1118-1125. [CrossRef]

33. Soedarmanto, I.; Kanbar, T.; Ulbegi-Mohyla, H.; Hijazin, M.; Alber, J.; Lammler, C.; Akineden, O.; Weiss, R.; Moritz, A.; Zschock, M. Genetic relatedness of methicillin-resistant Staphylococcus pseudintermedius (MRSP) isolated from a dog and the dog owner. Res. Vet. Sci. 2011, 91, E25-E27. [CrossRef] [PubMed]

34. Van Hoovels, L.; Vankeerberghen, A.; Boel, A.; Van Vaerenbergh, K.; De Beenhouwer, H. First case of Staphylococcus pseudintermedius infection in a human. J. Clin. Microbiol. 2006, 44, 4609-4612. [CrossRef] [PubMed]

35. Guardabassi, L.; Schmidt, K.R.; Petersen, T.S.; Espinosa-Gongora, C.; Moodley, A.; Agerso, Y.; Olsen, J.E. Mustelidae are natural hosts of Staphylococcus delphini group A. Vet. Microbiol. 2012, 159, 351-353. [CrossRef] [PubMed]

36. Magleby, R.; Bemis, D.A.; Kim, D.; Carroll, K.C.; Castanheira, M.; Kania, S.A.; Jenkins, S.G.; Westblade, L.F. First reported human isolation of Staphylococcus delphini. Diagn. Microbiol. Infect. Dis. 2019, 94, 274-276. [CrossRef]

37. Nikolaisen, N.K.; Lassen, D.C.K.; Chriel, M.; Larsen, G.; Jensen, V.F.; Pedersen, K. Antimicrobial resistance among pathogenic bacteria from mink (Neovison vison) in Denmark. Acta. Vet. Scand. 2017, 59, 60. [CrossRef]

38. Novakova, D.; Sedlacek, I.; Pantucek, R.; Stetina, V.; Svec, P.; Petras, P. Staphylococcus equorum and Staphylococcus succinus isolated from human clinical specimens. J. Med. Microbiol. 2006, 55, 523-528. [CrossRef]

39. Yoon, S.H.; Ha, S.M.; Kwon, S.; Lim, J.; Kim, Y.; Seo, H.; Chun, J. Introducing EzBioCloud: a taxonomically united database of $16 \mathrm{~S}$ rRNA gene sequences and whole-genome assemblies. Int. J. Syst. Evol. Microbiol. 2017, 67, 1613-1617. [CrossRef]

40. Mellmann, A.; Becker, K.; von Eiff, C.; Keckevoet, U.; Schumann, P.; Harmsen, D. Sequencing and staphylococci identification. Emerg. Infect. Dis. 2006, 12, 333-336. [CrossRef]

41. Kumar, S.; Stecher, G.; Li, M.; Knyaz, C.; Tamura, K. MEGA X: Molecular Evolutionary Genetics Analysis across computing platforms. Mol. Biol. Evol. 2018, 35, 1547-1549. [CrossRef]

42. Švec, P.; Pantůček, R.; Petráš, P.; Sedláček, I.; Nováková, D. Identification of Staphylococcus spp. using (GTG) 5 -PCR fingerprinting. Syst. Appl. Microbiol. 2010, 33, 451-456. [CrossRef]

43. Freiwald, A.; Sauer, S. Phylogenetic classification and identification of bacteria by mass spectrometry. Nat. Protoc. 2009, 4, 732-742. [CrossRef] [PubMed]

44. Wingett, S.W.; Andrews, S. FastQ Screen: A tool for multi-genome mapping and quality control. F1000 Research 2018, 7, 1338. [CrossRef] [PubMed]

45. Nurk, S.; Bankevich, A.; Antipov, D.; Gurevich, A.A.; Korobeynikov, A.; Lapidus, A.; Prjibelski, A.D.; Pyshkin, A.; Sirotkin, A.; Sirotkin, Y.; et al. Assembling single-cell genomes and mini-metagenomes from chimeric MDA products. J. Comput. Biol. 2013, 20, 714-737. [CrossRef] [PubMed]

46. Bushnell, B. BBMap Short-Read Aligner, and Other Bioinformatics Tools; Lawrence Berkeley National Lab.: Berkeley, CA, USA; Available online: http://sourceforge.net/projects/bbmap/ (accessed on 1 March 2019).

47. Darling, A.E.; Mau, B.; Perna, N.T. progressiveMauve: multiple genome alignment with gene gain, loss and rearrangement. PLoS ONE 2010, 5, e11147. [CrossRef]

48. Seemann, T. Prokka: rapid prokaryotic genome annotation. Bioinformatics 2014, 30, 2068-2069. [CrossRef] 
49. Yu, N.Y.; Wagner, J.R.; Laird, M.R.; Melli, G.; Rey, S.; Lo, R.; Dao, P.; Sahinalp, S.C.; Ester, M.; Foster, L.J.; et al. PSORTb 3.0: Improved protein subcellular localization prediction with refined localization subcategories and predictive capabilities for all prokaryotes. Bioinformatics 2010, 26, 1608-1615. [CrossRef]

50. Yu, C.S.; Cheng, C.W.; Su, W.C.; Chang, K.C.; Huang, S.W.; Hwang, J.K.; Lu, C.H. CELLO2GO: A web server for protein subCELlular LOcalization prediction with functional gene ontology annotation. PLoS ONE 2014, 9, e99368. [CrossRef]

51. Liu, B.; Zheng, D.; Jin, Q.; Chen, L.; Yang, J. VFDB 2019: A comparative pathogenomic platform with an interactive web interface. Nucleic Acids Res. 2019, 47, D687-D692. [CrossRef]

52. Xu, L.; Dong, Z.; Fang, L.; Luo, Y.; Wei, Z.; Guo, H.; Zhang, G.; Gu, Y.Q.; Coleman-Derr, D.; Xia, Q.; et al. OrthoVenn2: A web server for whole-genome comparison and annotation of orthologous clusters across multiple species. Nucleic Acids Res. 2019, 47, W52-W58. [CrossRef]

53. Arndt, D.; Grant, J.R.; Marcu, A.; Sajed, T.; Pon, A.; Liang, Y.; Wishart, D.S. PHASTER: A better, faster version of the PHAST phage search tool. Nucleic Acids Res. 2016, 44, W16-W21. [CrossRef]

54. Couvin, D.; Bernheim, A.; Toffano-Nioche, C.; Touchon, M.; Michalik, J.; Néron, B.; Rocha, E.P.C.; Vergnaud, G.; Gautheret, D.; Pourcel, C. CRISPRCasFinder, an update of CRISRFinder, includes a portable version, enhanced performance and integrates search for Cas proteins. Nucleic Acids Res. 2018, 46, W246-W251. [CrossRef] [PubMed]

55. Petkau, A.; Stuart-Edwards, M.; Stothard, P.; Van Domselaar, G. Interactive microbial genome visualization with GView. Bioinformatics 2010, 26, 3125-3126. [CrossRef] [PubMed]

56. Okonechnikov, K.; Golosova, O.; Fursov, M. Unipro UGENE: A unified bioinformatics toolkit. Bioinformatics 2012, 28, 1166-1167. [CrossRef] [PubMed]

57. Sullivan, M.J.; Petty, N.K.; Beatson, S.A. Easyfig: A genome comparison visualizer. Bioinformatics 2011, 27, 1009-1010. [CrossRef]

58. Yoon, S.H.; Ha, S.M.; Lim, J.; Kwon, S.; Chun, J. A large-scale evaluation of algorithms to calculate average nucleotide identity. Antonie van Leeuwenhoek 2017, 110, 1281-1286. [CrossRef]

59. Na, S.I.; Kim, Y.O.; Yoon, S.H.; Ha, S.M.; Baek, I.; Chun, J. UBCG: Up-to-date bacterial core gene set and pipeline for phylogenomic tree reconstruction. J. Microbiol. 2018, 56, 280-285. [CrossRef]

60. Cole, K.; Foster, D.; Russell, J.E.; Golubchik, T.; Llewelyn, M.; Wilson, D.J.; Crook, D.; Paul, J.; Modernising Medical Microbiology Consortium. Draft genome sequences of 64 type strains of 50 species and 25 subspecies of the genus Staphylococcus Rosenbach 1884. Microbiol. Resour. Announc. 2019, 8, e00062-19. [CrossRef]

61. Stepan, J.; Pantucek, R.; Doskar, J. Molecular diagnostics of clinically important staphylococci. Folia Microbiol. 2004, 49, 353-386. [CrossRef]

62. Richter, M.; Rossello-Mora, R. Shifting the genomic gold standard for the prokaryotic species definition. Proc. Natl. Acad. Sci. USA 2009, 106, 19126-19131. [CrossRef]

63. Becker, K.; Harmsen, D.; Mellmann, A.; Meier, C.; Schumann, P.; Peters, G.; von Eiff, C. Development and evaluation of a quality-controlled ribosomal sequence database for $16 \mathrm{~S}$ ribosomal DNA-based identification of Staphylococcus species. J. Clin. Microbiol. 2004, 42, 4988-4995. [CrossRef]

64. Ah Tow, L.; Cowan, D.A. Dissemination and survival of non-indigenous bacterial genomes in pristine Antarctic environments. Extremophiles 2005, 9, 385-389. [CrossRef] [PubMed]

65. van Elk, C.E.; Boelens, H.A.M.; van Belkum, A.; Foster, G.; Kuiken, T. Indications for both host-specific and introduced genotypes of Staphylococcus aureus in marine mammals. Vet. Microbiol. 2012, 156, 343-346. [CrossRef] [PubMed]

66. Wayne, R.K. Molecular evolution of the dog family. Trends Genet. 1993, 9, 218-224. [CrossRef]

67. Aarestrup, F.M. Comparative ribotyping of Staphylococcus intermedius isolated from members of the Canoidea gives possible evidence for host-specificity and co-evolution of bacteria and hosts. Int. J. Syst. Evol. Microbiol. 2001, 51, 1343-1347. [CrossRef] [PubMed]

68. Pantǔček, R.; Sedláček, I.; Petráš, P.; Koukalová, D.; Švec, P.; Štětina, V.; Vancanneyt, M.; Chrastinová, L.; Vokurková, J.; Růžičková, V.; et al. Staphylococcus simiae sp. nov., isolated from South American squirrel monkeys. Int. J. Syst. Evol. Microbiol. 2005, 55, 1953-1958. [CrossRef] [PubMed]

69. Suzuki, H.; Lefebure, T.; Bitar, P.P.; Stanhope, M.J. Comparative genomic analysis of the genus Staphylococcus including Staphylococcus aureus and its newly described sister species Staphylococcus simiae. BMC Genom. 2012, 13, 3. [CrossRef] 
70. Tong, S.Y.; Schaumburg, F.; Ellington, M.J.; Corander, J.; Pichon, B.; Leendertz, F.; Bentley, S.D.; Parkhill, J.; Holt, D.C.; Peters, G.; et al. Novel staphylococcal species that form part of a Staphylococcus aureus-related complex: the non-pigmented Staphylococcus argenteus sp. nov. and the non-human primate-associated Staphylococcus schweitzeri sp. nov. Int. J. Syst. Evol. Microbiol. 2015, 65, 15-22. [CrossRef]

71. Fitzgerald, J.R. The Staphylococcus intermedius group of bacterial pathogens: species re-classification, pathogenesis and the emergence of methicillin resistance. Vet. Derm. 2009, 20, 490-495. [CrossRef]

72. Canver, M.C.; Tekle, T.; Compton, S.T.; Callan, K.; Burd, E.M.; Zimmer, B.L.; Bemis, D.A.; Carroll, K.C.; Westblade, L.F. Performance of five commercial identification platforms for identification of Staphylococcus delphini. J. Clin. Microbiol. 2019, 57, e00721-19. [CrossRef]

73. Chua, K.Y.; Stinear, T.P.; Howden, B.P. Functional genomics of Staphylococcus aureus. Brief Funct. Genom. 2013, 12, 305-315. [CrossRef]

74. Ingmer, H.; Gerlach, D.; Wolz, C. Temperate phages of Staphylococcus aureus. Microbiol. Spectr. $2019,7$. [CrossRef]

75. Maslanova, I.; Stribna, S.; Doskar, J.; Pantucek, R. Efficient plasmid transduction to Staphylococcus aureus strains insensitive to the lytic action of transducing phage. FEMS Microbiol. Lett. 2016, 363, fnw211. [CrossRef] [PubMed]

76. Pires Dos Santos, T.; Damborg, P.; Moodley, A.; Guardabassi, L. Systematic review on global epidemiology of methicillin-resistant Staphylococcus pseudintermedius: Inference of population structure from multilocus sequence typing data. Front. Microbiol. 2016, 7, 1599. [CrossRef] [PubMed]

77. Novick, R.P.; Christie, G.E.; Penades, J.R. The phage-related chromosomal islands of Gram-positive bacteria. Nat. Rev. Microbiol. 2010, 8, 541-551. [CrossRef] [PubMed]

78. Fillol-Salom, A.; Martinez-Rubio, R.; Abdulrahman, R.F.; Chen, J.; Davies, R.; Penades, J.R. Phage-inducible chromosomal islands are ubiquitous within the bacterial universe. ISME J. 2018, 12, 2114-2128. [CrossRef]

79. Becker, K.; Keller, B.; von Eiff, C.; Bruck, M.; Lubritz, G.; Etienne, J.; Peters, G. Enterotoxigenic potential of Staphylococcus intermedius. Appl. Env. Microbiol. 2001, 67, 5551-5557. [CrossRef]

80. Hendricks, A.; Schuberth, H.-J.; Schueler, K.; Lloyd, D.H. Frequency of superantigen-producing Staphylococcus intermedius isolates from canine pyoderma and proliferation-inducing potential of superantigens in dogs. Res. Vet. Sci. 2002, 73, 273-277. [CrossRef]

81. Iyori, K.; Hisatsune, J.; Kawakami, T.; Shibata, S.; Murayama, N.; Ide, K.; Nagata, M.; Fukata, T.; Iwasaki, T.; Oshima, K.; et al. Identification of a novel Staphylococcus pseudintermedius exfoliative toxin gene and its prevalence in isolates from canines with pyoderma and healthy dogs. FEMS Microbiol. Lett. 2010, 312, 169-175. [CrossRef]

82. Futagawa-Saito, K.; Makino, S.; Sunaga, F.; Kato, Y.; Sakurai-Komada, N.; Ba-Thein, W.; Fukuyasu, T. Identification of first exfoliative toxin in Staphylococcus pseudintermedius. FEMS Microbiol. Lett. 2009, 301, 176-180. [CrossRef]

83. Nishifuji, K.; Sugai, M.; Amagai, M. Staphylococcal exfoliative toxins: "Molecular scissors" of bacteria that attack the cutaneous defense barrier in mammals. J. Derm. Sci. 2008, 49, 21-31. [CrossRef]

(C) 2020 by the authors. Licensee MDPI, Basel, Switzerland. This article is an open access article distributed under the terms and conditions of the Creative Commons Attribution (CC BY) license (http://creativecommons.org/licenses/by/4.0/). 